\title{
Mobile ethnography: emergence, techniques and its importance to geography
}

\author{
Andre Novoa
}

Northeastern University, USA

This paper presents an overview of the emergence of mobile ethnography and its potential benefits to the discipline of geography. The rise of mobile ethnography has been linked with the so-called "new mobilities paradigm", which has become especially important in geographical thinking over the past ten years. Erstwhile focused on more static concepts, such as space, place or landscape, geography is today rife with theories and analyses of movement, mobility and flow. In spite of that, mobile ethnography can soon claim a preeminent status within the discipline. In this paper, I document the rise of this methodology, focusing myself on three main aspects. The first is to attempt a definition of mobile ethnography itself. The second is to enlist some recent examples of its usages. The third is to provide several strategies and techniques arising from my own work. This paper might, thus, be useful to senior undergraduate and postgraduate students focused on qualitative research methods in geography.

Key Words: Mobility, Ethnography, Mobile Ethnography, Methodology, Methods.

Article Info: Received: March 5, 2015; Revised: May 5, 2015; Accepted: May 20, 2015; Online: May 30, 2015.

\section{Introduction}

This paper presents an overview of the emergence of mobile ethnography and its potential benefits to the discipline of geography. The paper is divided into four parts. The first contextualises the emergence of mobile ethnography, in general, and its links to the discipline of geography. In the second part, I attempt a definition of mobile ethnography itself, drawing upon scholars of the so-called "new mobilities paradigm" (Sheller and Urry 2006). The third section is an up-to-date state of the art on the latest works that have put this methodology to practice, especially in the field of geography and contiguous disciplines. A fourth part offers an array of strategies and techniques, arising from my own work as a mobile ethnographer. A conclusion folds the paper.

\section{Correspondence address}

Address: Andre Novoa, Humanities Center, Northeastern University, 450D Renaissance

Park, Boston MA 02115, USA.

Phone: (+351)916498727 | Email: novoa.andre@gmail.com 


\section{Ethnography goes mobile?}

It is arguable that ethnography has always been mobile. Indeed, the first generation of ethnographers, dating back to the likes of Bronislaw Malinowski and his disciples, probably experienced deeper sensations of displacement and mobility than most (mobile) ethnographers do today. As this generation ventured into far out islands in the pacific (Malinowski 1922, Mead 1928), wild jungles in South America (LeviStrauss 1948), deep African regions (Evans-Pritchard 1969) or inhospitable Australian deserts (Radcliffe-Brown 1930), their practices of mobility were long, brutal and dangerous. Ethnography always involved hard voyages. To a certain extent, this performance of mobility was, in itself, a decisive rite of passage into becoming an ethnographer. Ethnographers were to humanities what explorers, such as Jacques Cousteau or Roald Amundsen, were to physical sciences. Despite all this, the concept of mobile ethnography is a relatively new one, disputably first coined by John Urry and Mimi Sheller circa ten years ago (Sheller and Urry 2006).

So, why is it only now that mobile ethnography, as a concept, has surfaced? Why has it become necessary to make the word mobile explicit, rather than implicit? Evidence suggests that this has to do with the fact that mobility itself has only recently been given attention as a fundamental concept of social sciences and humanities - namely with the so-called rise of the "new mobilities paradigm".

In On the move, Tim Cresswell argues that academia drifted from a metaphysics of fixity to a metaphysics of flow in the last quarter of the twentieth century. This rendered a new stereotypical vision of social reality. In fact, "if something can be said to be fluid, dynamic, in flux, or simply mobile, then it is seen to be progressive, exciting, and contemporary", while "if something is said to be rooted, based on foundations, static, or bounded, then it seen to be reactionary, dull, and of the past" (Cresswell 2006: 25). In a way then, as the world became more mobile, so have our ways of apprehending the world. Mobile ethnography is, thus, not only highlighting a practical performance of the ethnographer (as it implies a physical continuous displacement) as much as it is emphasising the need to explore mobile phenomena from a theoretical and analytical point of view. In short, mobile ethnography implies both a practical and a theoretical dimension of mobility, simultaneously.

The history of mobile ethnography can be traced back to the works of George Marcus in the 90s, namely to his notion of multi-sited ethnography. Marcus pledged to follow "people, things, ideas, metaphors and biographies" around in an attempt to better grasp an increasingly mobile world, whilst deconstructing ethnography as an umbilically localised methodology (Marcus 1995, 1998). As Karen O'Reilly explains, in a direct reference to works dating back to the 90 s, "in the context of increased global interconnectivity, and mobility of people, objects and ideas, ethnographers are taking their methodology to multiple and mobile places and spaces" (O'Reilly 2009, p. 144). The trend steadily grew during the 90s, coming to be appropriated and re-launched into debate by Urry and Sheller, ten years later, as mobile ethnography. In spite of this, the emergence of mobile ethnography has been linked with the rise of the "new mobilities paradigm" as an acclaimed paradigm in social sciences and humanities, which has become of particular relevance to contemporary geographers.

Geography has been constructed, as a discipline, around five or six key concepts. Clifford, Holloway, Rice and Valentine enlist space, time, place, scale and 
landscape as these (Clifford et al 2009). Other scholars include territory, location or environment. Much of geographical thought (Cresswell 2013) has been build around these concepts. Particularly striking is how notions of movement, flow or mobility have been historically absent from the core thinking of the discipline. This commenced to change with the turn of the century, which saw the rise of the mobilities turn. Ever since, geographers have paid close attention to this new paradigm up to the point that "mobilities scholars" have become mainstream within the discipline (Adey 2010, Cresswell 2014).

Due to this, I posit that mobile ethnography can be especially beneficial to geography, as it has the potential to explore mobile phenomena with a particular insight and perceptiveness. In short, as mobility becomes a growing mainstream concept explored by geographers, progressively drawn into the core of geographical reasoning, so it seems logical that new mobile methods emerge (see Hein et al 2008). Mobile ethnography is one of these.

\section{Defining mobile ethnography}

Mimi Sheller and John Urry advocated that "there are several emerging forms of 'mobile ethnography', which involve participation in patterns of movement while conducting ethnographic research" (Sheller and Urry 2006, p.217). One year later, in his solo book Mobilities, Urry explains more thoroughly what he means by mobile ethnography: it can "involve 'walking with', or travelling with people, as a form of sustained engagement within their worldview. Through such 'co-present immersion' the researcher moves within modes of movement and employs a range of observation and recording techniques. It can also involve 'participation-whileinterviewing', in which the ethnographer first participates in patterns of movement, and then interview people, individually or in focus groups, as to how their diverse mobilities constitute their patterning of everyday life" (Urry 2007, p.40). In the same year, Barbara Czarniawska published Shadowing and other techniques for doing fieldwork in modern societies (Czarniawska 2007).

The book is a comprehensive guidebook into the techniques of following people around, mapping their movements and drawing a theoretical body from the data collected. Mobile ethnography is a translation of traditional participant observation onto contexts of mobility. It means that the ethnographer is not only expected to observe what is happening, but also to experience, feel and grasp the textures, smells, comforts and discomforts, pleasures and displeasures of a moving life. It means following people around and engaging with their worldviews. It means focusing on mobility.

Even though it only started to be formulated over the last decade, mobile ethnography has become increasingly important within academia ever since. Two published books on mobile methods centre some attention in this technique of study. The first one is co-authored by Büscher, Witchger and Urry himself: Mobile methods. The book seeks to challenge the new opportunities of researching mobile phenomena. Deeply tied with the new mobilities paradigm, the book brings together a collection of cutting-edge technical innovations informed by ethnographic and sociological ways-of-doing. As the authors put it, "in this book we address some problems and opportunities of doing research which respond to 
these challenges by trying to move with, and to be moved by, the fleeting, distributed, multiple, non-causal, sensory, emotional and kinaesthetic" (Büscher et al 2011, p.1). A particular interest is given to moving along with people, enabling new forms of ethnographical work, i.e. traditional participant-observation, but, this time around, whilst on the move. As the authors assert, "inquiries on the move such as the shadowing, stalking, walk-alongs, ride-alongs, participatory interventions and biographies we describe - enable questions about sensory experience, embodiment, emplacement, about what changes and what stays the same, and about the configuration and reconfiguration of assemblies of objects, spaces, people, ideas and information" (Büscher et al 2011, p.13).

These last ideas mesh well with the ones offered by its twin-book: Mobile methodologies. In the introductory chapter, the editors, Ben Fincham, Mark McGuinness and Lesley Murray, call attention to the importance of "being there", of being able to capture mobilities in situ, which consequently means to move along with people (Fincham et al 2010, p.5). Feeling and participating in the everyday movements of individuals, whilst doing interviews and gathering other data, is of paramount relevance, not only because the researcher has the opportunity to observe people, but also because it allows for a physical "co-presence" that permits him or her to undergo those same activities.

The trend here is to do what the editors call "first-hand social science", i.e. to understand and apprehend phenomenon in the immediacy of the events. Despite differences in how scholars label the practice, there is a consensus on the necessity of being at hand and capturing mobile practices (as well as the meanings that individuals confer to them) on the immediacy.

Mobile ethnography can thus be defined by a mobile participant-observation with a particular focus on mobile phenomena. As we saw previously, it can be argued that ethnography has always been a mobile method, seeing as it has continuously enforced some kind of de-territorialisation from the ethnographer - when not physical, at least a metaphorical displacement. However, mobile ethnography is particularly engaged with following people around in their itinerancies whilst focusing on mobile phenomena. That is, mobile ethnography is doubly entangled with and by mobility, seeing as it not only encourages a practical, physical movement by the researcher but it also requires the ethnographer to focus on the relevance of mobility itself. Mobile ethnography is practically and epistemologically linked with mobility. This is what differentiates it from other approaches and takes on ethnographic work.

There are very different ways of doing mobile ethnography. It can be done, for instance, in/within small-scale geographies or, alternatively, in/within a large-scale frame. It can involve cross-border mobility or more quotidian commutes between work and home. It can also involve very different types and systems of transportation. What seems to bind all of these together is a focus on mobility and mobile phenomena. Mobile ethnography, as a mobile practice, ontologically comprises a focus on mobility. How do individuals produce meaning of their mobilities? How do individuals inhabit mobile spatialities? How does movement affect their lives? How does movement impact on their practices, representations and worldviews? There is an ontological spotlight on dynamics of flow, movement and mobility. Even when one proposes to examine the transformation of space into place in these contexts, they are automatically done against a backdrop of mobility. Mobility 
hermeneutically and epistemologically informs this type of method. Let us briefly pass through some examples of mobile ethnographies done in the recent years.

\section{Examples of mobile ethnography}

Laura Watts' ethnography of train travel is one of the most paradigmatic usages of this recent methodology. Through a train journey across the UK, Watts engages a mobile participant observation, recording and registering the practices of passengers. The author experiences train mobility herself, whilst taking photographs and recordkeeping daily and mundane rhythms of the individuals that surround her. Watts comes to the conclusion that "the art and craft of train travel is not simply an abstract or theoretical making of space and time. It is skilled and tiring work, which manipulates and is manipulated by an irrepressibly social and material world to create a moving experience" (Watts 2008, p.723).

These ideas were more recently refurbished in a collaborative paper with Glenn Lyons. The authors used a travel remedy kit - "an intervention- and interviewbased piece of empirical research (...) which seeks to encourage individuals to discuss and rethink their travel choices and behaviours" (Watts and Lyons 2011, p.106). The kit forced people to think about what they value the most in train journeys, helping the authors to critically analyse how people create a familiar environment or spatiality when on the move, thus stating that "the ideal length of a journey does no tend to zero" (Watts and Lyons 2011, p.116).

Juliet Jain used mobile ethnographic methods to explore bus journeys. The author's main concern was "the making of the bus journey: setting out, waiting, the unfolding rhythms of the journey, and the performances of bus passengers" (Jain 2009, 91). Through submerging herself in bus travel in the UK, Jain explains that this type of travelling is very distinct from all others, containing its own moments, tempos, and actions. As she puts it, "an empty bus can flow seamlessly, its carcass ambivalent to place. Passengers in making the mundane journey transform this stage (...). Passengers draw the outside into the bus through their gaze, experiencing the sun or the darkness of night" (Jain 2009, p.105).

A day journey is eminently different, as an embodied practice, from a night journey as passengers affect the "tempo of flow through talk, music, reading" (Jain 2009 , p.105), and so forth. These notions could only be unfolded through the usage of mobile ethnographic techniques. One other fascinating account of itinerant ethnography is to be found in the works of Eric Laurier. The author focuses on empirical data retrieved from a video-ethnography of one specific driver that made use of his vehicle both as means of transportation and an office at the same time. Laurier recorded a regular daily driving experience of Ally, a female business-executive, and used it to question assumptions on speed and slowness.

The paper is generally about "doing office work on the motorway", wherein the author questions if "we can speculate on whether we could have a world where business travellers were the slow travellers among us and not just on the motorway", seeing as "being a fast driver and an office worker is a morally precarious position to attempt to achieve" (Laurier 2004, p.273). Through the usage of mobile ethnography, Laurier was able to cogitate around the many moralisations of the fast and the slow, specifically how business travel does not necessarily mean fast, 
smooth and frictionless movement, even though Ally "claimed a certain entitlement to travel faster than ordinary motorways users", just as if she was a business class traveller effortlessly passing by airport check-ins and lounges. More recently, Laurier, in collaboration with Hayden Lorimer, used once again a video-mobile technique to reflect on what they called the "landscapes of commuting" (Laurier and Lorimer 2012) - other authors who used video techniques in relation to the study of mobile subjects and mobile practices include Justin Spinney, Sarah Pink and Bradley Garrett (Spinney 2011, Pink 2007, Garrett 2011).

Walking is another practice that has been capturing some interest amongst scholars and several ethnographic accounts done with walkers have been attempted. Tim Ingold's paper on walking documents that "in real life, for the most part, we do not perceive things from a single vantage point, but rather by walking around them", claiming that "walking is itself a form of circumambulatory knowing” (Ingold 2004, p.331).

The author is calling for a more grounded approach to human movement, wherein the "embodied skills of footwork" may open new terrains for social enquiry in the areas of "environmental perception, the history of technology, landscape formation and human anatomical evolution” (Ingold 2004, p.315). This is what several authors have generally attempted over the last few years, namely Hayden Lorimer, David Pinder or Phil Smith (Lorimer 2010, Pinder 2011, Smith 2010), occasionally drawing upon the works of authors such as Jenks and Neves or Kramer and Short who used ethnographic methods to explore the resurgence of the figure of the flâneur (Jenks and Neves 2000, Kramer and Short 2011).

Philip Vannini was probably the first author who engaged with mobile ethnography outside the asphalt and land-based realms. The author examines dimensions related to mobility, place and time on Canada's West Coast through ethnography on ferryboats. Vannini did circa 250 ferry trips, 400 interviews in three-dozen island and coastal communities as well as website tell stories, producing several tales of the quotidian practices and rhythms of the everyday life inside these boats. In these Canadian communities, it is nearly impossible to escape daily commutes of several hours; sometimes, hitting the nearest grocery store means 36 hours of travelling. Vannini recounts these stories in an attempt to answer questions about time, space and mobility. What does time mean in a situation like this? What is home? What does mobility stand for: a means or an end? "In a nutshell, if my basic research question was to determine what roles ferries play in day-to-day life, the answer is that they play multiple roles - indeed so many that the lives in coastal or island community are incomprehensible without thinking about ferry boats" (Vannini 2012) (see also Vannini 2011 a, 201 1b, 2011c).

One other important account of mobile ethnography is Brian Howell's exploration of short-term missions. The author uses ethnography to explore Christian travel, exploring questions of tourism and pilgrimage through several in-depth interviews alongside a fieldtrip to the Dominican Republic. Howell uses a classic display of techniques, such as field diaries, notes and interviews, but it is interesting to see how this is done on the move. Although Howell did not frame his research within the mobilities turn, I still posit that his work is a relevant contribution to the formulation of mobile ethnographic techniques. "The central argument of this book is that we produce narrative - framing discourses - that profoundly shape the experiences of these travels" (Howell 2012, p.9). It is thus about how a certain 
representation of mobility, in the ways described by Cresswell (Cresswell 2006), shapes and informs the practice of mobility itself, clearly dialoguing, even if not on purpose, with recent discussions arising from the mobilities paradigm.

Anders Blok also provided an interesting claim for the usage of mobile ethnographic methods, cross-referencing it with Actor-Network-Theory. The author proposes a turn towards what he calls an ethno-socio-cartography methodology, i.e. a type of ethnography that is eminently mobile and specifically interested in the formation of "situated globalities" (Blok 2010, p.509). Blok frowns at the ontological dichotomy created by the debates on the local and the global, insisting that the local is where the global is produced and reproduced, rather than forming a backdrop of embrace or resistance. Through an empirical analysis of Japanese whaling, the author sheds light on how "seemingly contradictory qualities - of being both global and micro - are exactly what I need to illustrate my methodological claims" (Blok 2010, p.509). Seeing as the global is a web of endless networks and flows, permanently operating at micro-scales, Blok suggests that the researcher should commit to the study of little mobilities that, nevertheless, unfold the global.

\section{Strategies and techniques}

Mobile ethnography is, thus, a rich methodological terrain (still) in formation. It engages with different scales and diverse types of mobilities. Mobile ethnography can be conducted to explore many different realms of mobility, ranging from automobility to maritime mobilities, public transportation in urban contexts or even the simple task of walking. Furthermore, it can be deployed to analyse a multitude of scales, ranging from daily commutes to translocal and transnational mobilities. In this section, I make some suggestions on possible strategies and techniques for doing large-scale mobile ethnography, based on my own personal work. I have conducted mobile fieldwork with musicians, truck drivers and politicians. I wish to highlight three particular aspects.

\section{Privacy issues and possible strategy}

When doing mobile ethnography, there are profound privacy issues that deeply define one's work. These are much more evident when using this particular form of fieldwork than with more traditional ethnographic methods. When one is on the road with an individual or a group of individuals, one is constantly with them. Whereas in more localised practices both the ethnographer and the informants are able to create, negotiate and define private zones more clearly - this could be a room, an apartment, a house or a tent - when deploying mobile methods one is often in the position of sharing the same spaces almost all of the time. This produces serious challenges for the ethnographer.

When I performed fieldwork with lorry drivers, I drove, ate and slept in the same truck as the drivers for periods between two days to an entire week. When fieldworking with MEPs, each one of us had our own hotel room, but I followed them around in airplanes, official cars, stations, lounges, private meetings, and so forth. Finally, when touring with a band, one is not only together with the musicians during the long drives (which is almost a third of the total time spent on tour), but 
often ends up sleeping in the same rooms. This may seem trivial, but it is very demanding of the ethnographer and the informants. Hence, my personal strategy has been to go on the road for periods of roughly one week to two weeks, after which returning home, before hitting the road once again with the same individual or group of individuals. Mobile ethnography may, thus, require several entry and exit points, which end up shaping and informing the research. To do mobile ethnography may signify engaging with shorter, but more intense field trips.

I believe this may be labelled as best-practice for mobile ethnography. Although it may be demanding to create these entry and exit points consecutively, they also provide the chance for the ethnographer to distance him or herself from the field and recalibrate the research, both in terms of the theories used and the analytical angles. This can be worked as an advantage in relation to more traditional forms of ethnography. Furthermore, it also alleviates a set of complicated ethical issues related to privacy. Asking to shadow someone for a week is not the same as asking for a period of three or more months. Hence, it may be it that this strategy is what makes this particular way of doing ethnography possible.

To sum up, I return to Czarniawska, who sheds light on how the technique of "shadowing" is crucial in offering a "unique opportunity for self-observation and self-knowledge" whilst being "a way that mirrors the mobility of contemporary life". However, it also carries some obstacles. It is a method that "requires constant attention and continuous ethical decisions" and is "psychologically uncomfortable" (Czarniawska 2007, p.58).

\section{Analysing practices}

When on the move, the ethnographer should be especially attentive of the small and quotidian details of everyday life that may contain the potential to develop or question big theories. As Marylin Strathern once put it, "if one can ask 'big' questions of 'small' data, then the difference between big and small disappears" (Strathern 2004, p. xx). These are normally tied to issues and problematics of mobility. The production of fieldwork diaries, where one registers all the timetables, routines and rhythms, is a standard procedure. These include daily routines such as waking up, going to be, having meals, performing specific tasks, and so on. The study of rhythms is a well-established procedure in the realm of humanities and particularly in geography. For instance, in Reanimating places: a geography of rhythms, editor Tom Mels and the remainder of the authors make clear that timespace rhythms accentuate the practical, symbolic, everyday and embodied qualities of our mundane experiences as well as contribute to the making of our geographical environment (Mels 2004).

The study of routines and rhythms may unveil hidden social dynamics that structure the individuals' lives. This is one of the first dimensions that should preoccupy the ethnographer when fieldworking on the move.

\section{Analysing meanings}

The ethnographer should also try to register most of the informants' comments and takes on things, in order to apprehend underlying and collective discourses. Delving into the production of meaning and representation, so that one can have a 
clear grasp of personal and collective idiosyncrasies, is of paramount importance, complementing well the study of practices. The researcher should, then, relate these to issues of mobility, analysing a wide range of themes that encompass the impact of mobility in the informants' lives, the discourses on having to live in permanent itinerancy, the struggles and pleasures of a mobile life or how mobility is generically conceived by them (what does it mean? Pleasure, pain, toll, freedom?). If unconscious, mechanical and quotidian practices are relevant when doing ethnography, so are the individuals' words and the meanings they bestow to their practices. Words and expressions as well as personal and collective discourses confer part, if not most, of the meaning to the practices themselves. Sometimes expressions and phrases expose layers of meaning that are hidden in the naturalness of personal and collective practices. Delving into these meanings, especially in relation to mobility, could be at the core of mobile ethnographic methods.

\section{Analysing sensations}

To further complement the analysis of practices and meanings, the research could analyse the sensations and feelings of mobility. I believe that a mobile ethnography should be particularly aware of this. Looking at, and experiencing it, if a particular pattern of mobility is grinding or liberating, comfortable or uncomfortable, pleasurable or unpleasant, tiring or relaxing may uncover significant data. In his book Keeping together in time, William McNeill highlighted the importance of coordinated movement in the creation of shared senses of belonging. The historian argued that synchronised mobility is a powerful force to generate bonds between people, ultimately bringing them together and forging a sense of community (McNeill 1997). In other words, collective sensations and feelings of mobility may be a prevailing phenomenon in coordinating the individuals' movement and imprinting meaning and sensations of belonging to their lives. Naturally, uncomfortable or restless mobilities can create difficult situations, but they nevertheless may work towards the fabrication of some kind of class-consciousness that can structure both the mobilities and the identities of the individuals under study.

\section{More techniques: photos, videos and interviews}

An intense observant-participation can render enough data to produce a vivid account of the mobile lives of the individuals under study. Even so, completing it with other techniques, including the production of photographic albums, videos and interviews, might prove itself useful. Photographic evidence can cast light, for instance, on the objects that people bring onto the road, or illustrate with visual references certain practices of the road. It can also be a good technique for the ethnographer to situate him or herself in his own travels, even if the photos do not make it to the final document. Videos, too, can be useful to replicate the sensations of life on the road, providing snapshots and vignettes of how certain practices link to particular feelings - Bradley Garrett makes a claim for a further usage of videographic techniques in geographic research (Garrett 2011). Finally, conducting structured or semi-structured interviews can be especially helpful into further enquiring the informants' meanings, representations and worldviews. Once again, a focus on mobile practices and mobile phenomena in general should be present. 


\section{Conclusion}

Mobile ethnography is here to stay. Emerging out of the "new mobilities paradigm", this methodology has become especially relevant to geographers, seeing how it has a natural propensity to deal with mobile phenomena, which has been increasingly pushed into the core of geographical reasoning. Erstwhile focused on more static concepts, such as space, place or landscape, geography is today rife with theories and analyses of movement, mobility and flow. In spite of that, mobile ethnography can soon claim a preeminent status within the discipline, with geographers following the footsteps of the authors enlisted above. As we saw, mobile ethnography entails a physical displacement from the ethnographer as much as it forces him or her to theoretically and analytically engage with mobility.

Mobile ethnography is, thus, doubly informed by mobility, both at a practical and a theoretical level. Doing mobile ethnography means moving while analysing movement. This methodology can be deployed to analyse a multitude of scenarios, scales (daily commutes, translocal mobilities, transnational movement) and types of mobilities (painful, pleasurable, work-related, touristic, etc.), while involving very different means of transportation, from automobility to aerial mobilities or walking. The ethnographer can use several strategies, such as the entry and exit points strategy aforementioned, and pay a close attention to the practices arising from mobility, the meanings/representations of mobility in the informants' worldviews and, finally, the sensations and feelings of mobility.

Taken together, these can provide a holistic view of how mobility structures the lives of the individuals under study. These can be complemented with photographic and videographic evidence, and interviews. In short, mobile ethnography is still a terrain in formation, but it has already fixed rich contributions to the study of contemporary life, namely from a geographical perspective.

\section{References}

Adey, P 2010, Mobility, Routledge, London.

Blok, A 2010, 'Mapping the super-whale: towards a mobile ethnography of situated globalities', Mobilities, vol. 5, no. 4, pp. 507-528.

Büscher, M, Urry, J \& Witchger, K 2011, Mobile Methods, Routledge, London.

Clifford, N, Holloway, S, Rice, S \& Valentine, G 2009, Key concepts in geography, SAGE, London.

Cresswell, T 2006, On the move: mobility in the modern Western world, Routledge, New York.

Cresswell, T 2013, Geographical thought: a critical introduction, Willey-Blackwell, Oxford.

Cresswell, T 2014, 'Mobilities III: moving on', Progress in Human Geography, vol. 38, no. 5, pp. 712-721.

Czarniawska, B 2007, Shadowing: and other techniques for doing fieldwork in modern societies, Copenhagen Business School Press, Malmö.

Evans-Pritchard, E 1969, The Nuer: a Description of the Modes of Livelihood and Political Institutions of a Nilotic People, Oxford University Press, Oxford.

Fincham, B, McGuinness, M \& Murray, L 2010, Mobile methodologies, Palgrave Macmillan, New York.

Garrett, B 2011, 'Videographic geographies: using digital video for geographic research', Progress in Human Geography, vol. 35, no. 4, pp. 521-541.

Hannam, K, Sheller, M \& Urry, J 2006, 'Editorial: mobilities, immobilities and moorings', 
Mobilities, vol. 1, no. 1, pp. 1-22.

Hein, J, Evans, J \& Jones, P 2008, 'Mobile methodologies: theory, technology and practice', Geography Compass, vol. 2, no. 5, pp. 1266-1285.

Howell, B 2012, Short-term mission: an ethnography of Christian travel narrative and experience, IVP Academic, Downers Grove.

Jain, J 2009, The making of mundane bus journeys, in P Vannini (ed), The culture of alternative mobilities: routes less travelled, Ashgate, Farnham.

Jenks, C \& Neves, T 2000, 'A walk on the wild side: urban ethnography meets the Flâneur', Cultural Values, vol. 4, no. 1, pp. 1-17.

Kramer, K \& Short, J 2011, 'Flânerie and the globalizing city', City, vol. 15, no. 3-4, pp. 322-342.

Laurier, E 2004, 'Doing office work on the motorway', Theory, Culture E Society, vol. 21, no. 4-5, pp. 261-277.

Laurier, E \& Lorimer, H 2012, 'Other ways: landscapes of commuting', Landscape Research, vol. 37 , no. 2, pp. 207-224.

Lévi-Straus, C 1948, 'La vie familiale et sociale des Indiens Nambikwara', Journal de la Société des Américanistes, vol. 37, pp. 1-132.

Malinowski, B 1922, Argonauts of the Western Pacific, Routledge \& Kegan Paul Ltd, London.

Marcus, G 1995, 'Ethnography in/of the world system: the emergence of multi-sited ethnography', Annual Review of Anthropology, vol. 24, pp. 95-117.

Marcus, G 1998, Ethnography through thick and thin Princeton, Princeton University Press.

McNeill, W 1997, Keeping Together in Time: Dance and Drill in Human History, Harvard University Press, Cambridge.

Mead, M 1928, Coming of age in Samoa: a psychological study of primitive youth for western civilisation, William Morrow and Co, New York.

Mels, T 2004, Reanimating places: a geography of rhythms, Ashgate, Aldershot.

O'Reilly, K 2009, Key concepts in ethnography, SAGE, London.

Pinder, D 2011, 'Errant paths: the poetics and politics of walking. Environment and Planning D', Society and Space, vol. 29, no. 4, pp. 672-692.

Pink, S 2007, 'Walking with video', Visual Studies, vol. 22, no. 3, pp. 240-252.

Radcliffe-Brown, A 1930, 'The social organization of Australian tribes', Oceania Publications, vol. 1, no. 2, pp. 206-246.

Sheller, M \& Urry, J 2006, 'The new mobilities paradigm', Environment and Planning A, vol. 38, no. 2, pp. 207-226.

Smith, P 2010, Mythogeography: a guide to walking sideways, Triarchy Press, Devon.

Spinney, J 2011, 'A chance to catch a breath: using mobile video ethnography in cycling research', Mobilities, vol. 6, no. 2, pp. 161-182.

Strathern, M 2004, Partial connections, Rowman \& Littlefield Publishers, Lanham.

Urry, J 2007, Mobilities, Polity, Cambridge.

Vannini, P 2011a, 'Constellations of ferry (im)mobility: islandness as the performance and politics of insulation and isolation', Cultural Geographies, vol. 18, no. 2, pp. 249-271.

Vannini, P 2011b, 'Constellations of (in-)convenience: disentangling the assemblages of Canada's west coast island mobilities', Social \& Cultural Geography, vol. 12, no. 5, pp. 471-492.

Vannini, P 2011c, 'Mind the gap: the tempo rubato of dwelling in lineups', Mobilities, vol. 6, no. 2, pp. 273-299.

Vannini, P 2012, Ferry Tales: Mobility, Place, and Time on Canada's West Coast, Routledge, New York.

Watts, L 2008, 'The art and craft of train travel', Social छ Cultural Geography, vol. 9, no. 6, pp. $711-726$.

Watts, L \& Lyons, G 2011, 'Travel Remedy Kit: interventions into train lines and passenger times', in M, Büscher, J, Urry, \& K Witchger (eds), Mobile Methods, Routledge, London. 